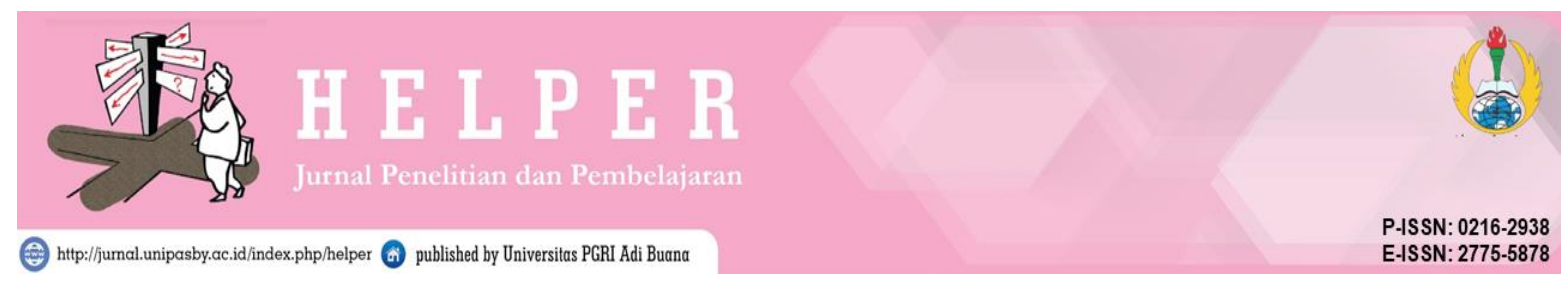

Vol. 38 No. 2 (2021)

\title{
MOTIVASI BELAJAR SISWA PADA PEMBELAJARAN DARING SISWA KELAS VIII-I SMPN 1 TAMAN SIDOARJO
}

\author{
Dhea Oktavia Rigma Wardani \\ ${ }^{1}$ Bimbingan dan Konseling, Universitas PGRI Adi Buana Surabaya, Surabaya, Indonesia \\ *Email: dheao352@gmail.com \\ Tamsil Muis \\ ${ }^{2}$ Bimbingan dan Konseling, Universitas PGRI Adi Buana Surabaya, Surabaya, Indonesia \\ *Email: tamsil.muis@ unipasby.ac.id
}

\begin{abstract}
Abstrak
Berbagai permasalahan yang sering terjadi di sekolah seperti Pembelajaran Daring Di era pandemi seperti penelitian ini bertujuan untuk mendeskripsikan peran guru bimbingan dan konseling dalam pembelajaran siswa secara Daring dan pengawasan terhadap orangtua saat anak nya melakukan pembelajaran secara daring dari rumah. Penelitian ini merupakan penelitian deskriptif kuantitatif. Populasi dalam penelitian ini terdiri dari 61 subjek. Sedangkan sampel penelitian terdiri dari 1 guru bimbingan dan konseling dan 3 siswa yang mengalami motivasi belajar rendah dan 3 Orangtua Siswa yang motivasi.Metode penilitan ini menggunakan deskriptif kuantitatif. Metode penelitian menggunakan angket dan wawancara. Analisis data dalam penelitian ini menggunakan penelitian deskriptif dengan tujuan untuk mendeskripsikan hasil penelitian. Hasil penelitian yang diperoleh adalah peran guru bimbingan dan konseling terbukti telah mampu mengurangi Motivasi belajar siswa kelas VIII-i di SMPN 1 Taman Sidoarjo, dengan perolehan uji regresi linear berganda 0,197. Adapun peran guru bimbingan dan konseling dalam Motivasi Belajar Siswa SMPN 1 Taman Sidoarjo yaitu guru bimbingan dan konseling selaku wali kelas VIII-i dan Orangtua untuk mengetahui apa penyebab kendala-kendala siswa saat melakukan pembelajaran secara Daring tersebut, kemudian guru bimbingan dan konseling memberikan arahan atau pengetahuan dan wawasan kepada siswa tentang manfaat pembelajaran secara daring.
\end{abstract}

Kata Kunci: Guru Bimbingan dan Konseling, Motivasi Belajar 
regression test of 0.197. The role of guidance and counseling teachers in Student Learning Motivation at SMPN 1 Taman Sidoarjo is the guidance and counseling teacher as homeroom teacher for class VIII-i and parents to find out what causes students' obstacles when doing online learning, then the guidance and counseling teacher provides direction or guidance. knowledge and insight to students about the benefits of online learning.

Keywords: The role of guidance and counseling teachers, learning motivation

\section{PENDAHULUAN}

Pada awal tahun 2020, dunia sedang waspada dengan sebuah virus yang disebut dengan corona virus yang menyebabkan penyakit COVID-19. COVID-19 menimbulkan penyakit mulai dari flu hingga dapat menimbulkan penyakit yang berat awalnya diduga adalah penyakit pneumonia, yang memiliki gejala seperti flu pada umumnya. Gejalanya adalah antaranya demam, batuk, letih, tidak nafsu makan dan sesak napas. Namun ternyata COVID-19 berbeda dengan flu biasa dan bahkan COVID-19 dapat berkembang dengan amat cepat sampai dapat mengakibatkan infeksi lebih parah dan gagal organ. Kondisi darurat ini terutama terjadi pada pasien dengan masalah kesehatan sebelumnya . COVID-19 adalah penyakit yang menular. COVID-19 dapat menular dengan mudah melalui batuk atau napas yang dikeluarkan oleh penderita COVID-19. Oleh karena itu, organisasi kesehatan dunia yaitu World Health Organization (WHO) menghimbau untuk menjaga jarak lebih dari 1 meter dari orang lain untuk meminimalisir penularan COVID-19.

Dengan adanya Covid-19 semua para siswa memulai pembelajaran work from home, perlu dilakukan penguatan pembelajaran secara daring sehingga kebutuhan pembelajaran tetap terpenuhi dengan pemanfaatan teknologi informasi dengan koordinasi yang baik antara siswa, guru, dan orang tua di rumah.. menurut Baharuddin dan Esa (2009: 11) Definisi belajar ini memiliki pengertian bahwa belajar adalah sebuah kegiatan untuk mencapai kepandaian atau ilmu belajar banyaknya siswa membuat motivasi rendah karena kurangnya pemahaman belajar antara guru dan siswa merupakan proses manusia untuk mencapai berbagai macam kompetensi, keterampilan dan sikap. Belajar dimulai sejak manusia lahir sampai akhir hayat. Sehingga membuat siswa tersebut menjadi malas belajar, nilai yang jelek. hasil penelitian tersebut terbukti pada siswa di SMPN 1 Taman, beberapa siswa yang motivasi belajar rendah sehingga nilai-nilai pada mata pelajaran menurun. Kebutuhan belajar daring harus didukung berbagai media yang mudah digunakan. menjelaskan bahwa pembelajaran daring yang efektif disusun untuk menyediakan sumber daya dan perangkat yang ideal bagi siswa. Ada banyak jenis aplikasi daring termasuk blog, wiki, web, aplikasi dalam gadget, dan kursus online. 
Senada dengan hal tersebut, Aplikasi tersebut terus digunakan hingga saat ini untuk menunjang pengetahuan dan kegiatan kolaborasi antar guru dan siswa. sehingga pemerintah di bebagai negara telah menerapkan lockdown atau karantina. Pembelajaran dilakukan dengan menggunakan media, baik media cetak (modul) maupun non cetak (audio/video), komputer/internet, siaran radio dan televisi.

Pada pembelajaran online, peserta didik dapat menjadi kurang aktif dalam menyampaikan aspirasi dan pemikirannya, sehingga dapat mengakibatkan pembelajaran yang menjenuhkan. Seorang siswa yang mengalami kejenuhan dalam belajar akan memperoleh ketidakmajuan dalam hasil belajar. Oleh karena itu, diperlukan pendorong untuk menggerakkan menggerakan siswa agar semangat belajar sehingga dapat memiliki prestasi belajar. Semangat belajar dapat dimiliki dengan meningkatkan motivasi belajar. Motivasi belajar adalah sebuah penggerak atau pendorong yang membuat seseorang akan tertarik kepada belajar sehingga akan belajar secara terus-menerus. Motivasi yang rendah dapat menybabkan rendahnya keberhasilan dalam belajar sehingga akan merendahkan prestasi belajar siswa. Oleh karena itu, dalam makalah kali ini akan membahas mengenai bagaimana cara meningkatkan motivasi belajar siswa pada pembelajaran online akibat pandemi COVID-19 Namun, semua itu tidak akan tercapai dengan optimal tanpa adaya fungsi kontrol dan bimbingan dari orang tua selama pembelajaran daring di rumah. Dibutuhkan pengawasan pembelajaran secara berkala dan sistematis, sehingga kegiatan belajar daring dapat berjalan dengan baik. Dibutuhkan strategi pola asuh orang tua yang tepat untuk memotivasi siswa dalam belajar. Orang tua merupakan lingkungan pertama kali yang anak temui, memberikan kontribusi besar dalam membentuk kepribadian seorang anak. Keluarga memiliki model pola asuh serta metode dalam memberikan Pendidikan.

\section{METODE}

Penelitian ini bertujuan untuk mendeskripsikan peran orangtua dalam pembelajaran siswa secara daring. Maka penelitian ini merupakan penelitian deskriptif kuantitatif. Metode penelitian kuantitatif merupakan salah satu jenis penelitian yang spesifikasinya adalah sistematis, terencana dan terstruktur dengan jelas sejak awal hingga pembuatan desain penelitiannya. Pendekatan penelitian ini menggunakan penedakatan kuantitatif karena menggunakan angka, mulai dari pengumpulan data, penafsiran terhadap data tersebut, serta penampilan dan hasilnya. Penelitian ini menggunakan penelitian deskriptif dengan tujuan untuk mendeskripsikan hasil penelitian. 
Adapun pengertian deskriptif menurut Sugiyono (2013) yaitu metode yang berfungsi untuk mendeskripsikan terhadap objek yang diteliti melalui data yang telah dikumpulkan sebagaimana adanya. Penelitian ini menggunakan deskriptif karena data yang didapatkan dideskripsikan secar deduksi berasal dari peran guru bimbingan dan konseling, lalu dengan wawancara dan angket untuk menguji validitas keberlakuan peran orangtua tersebut dan ditariklah kesimpulan tentang pembelajaran secara daring. Kemudian dijabarkan secara deskriptif, karena hasilnya juga melihat dalam bentuk rapor siswa dan angket akan diarahkan untuk mendeskripsikan data yang diperoleh dan untuk menjawab rumusan.

\section{HASIL PENELITIAN DAN PEMBAHASAN}

\section{Hasil Penelitian}

\section{A. Hasil Pembagian Angket}

Kemudian menentukan sebuah peran guru bimbingan dan konseling dengan menggunakan wawancara. Adapun rentang penelitian ini pada skala pengukuran perilaku Motivasi Belajar Siswa Pada Pembelajaran Daring.

Peneliti mengelolah data mengenai peran guru bimbingan dan konseling sebagai sampel yang telah di pilih yang mengalami perilaku Motivasi Belajar Siswa Pada Pembelajaran Daring mulai dari kategori tinggi, sedang, dan rendah. Maka, hal tersebut dapat diuraikan pada tabel dibawah ini:

Tabel 1 Skor Hasil Angket Motivasi Belajar Rendah disebarkan pada Wali Murid

\begin{tabular}{cccc}
\hline No. & Nama Siswa & Skor Total & Kategori \\
\hline 1. & Apel & 28 & Rendah \\
\hline 2. & Alamanda & 28 & Rendah \\
\hline 3. & Lily & 29 & Rendah \\
\hline
\end{tabular}

Selama masa pandemi siswa mengalami cenderung motivasinya rendah atau tinggi ialah Dari segi keseharian siswa mengalami cenderung menjalani seperti biasa meski di masa pandemi cuman pengukuran tugas dari semangat belajar terjadi penurunan secara tidak langsung karna minim nya kuota internet,hp yang hanya bisa menunggu mama atau ayah nya pulang baru bisa mengenakan hp kelemahan dari belajar secara daring itu lah menjadi 
kelemahan bagi siswa tidak bisa belajar daring dengan secara lancar. Faktor-Faktor penghambat motivasi belajar ialah faktor dari motivasi anak, dari karakter anak, dukungan kluarga, fasilitas jaringan internet. Saat pembelajaran secara daring faktor-faktor pendukung apa sajakah yang menjadi media belajar siswa ialah Perkembangan tekhnologi telah merubah sebagian besar cara hidup manusia dalam melakukan kegiatan. Setip hari, bahkan setiap saat tekhnologi dapat mempermudah sebuah proses yang tadinya sangat panjang, membutuhkan waktu serta tenaga dan biaya. Peran Guru BK Dalam Mengembangkan Motivasi Belajar Siswa Melalui Layanan Informasi di SMPN 1 Taman Sidoarjo ialah Peran utama guru di sekolah adalah menyampaikan ilmu pengetahuan sebagai warisan kebudayaan manusia masa lalu yang dianggap berguna sehingga harus diwariskan.Hambatan Guru BK Dalam Mengembangkan Motivasi Belajar Siswa Melalui Layanan Informasi di SMPN 1 Taman ialah Sebagai konselor sekolah tentu sangat menaruh harapan besar agar Bimbingan Konseling dapat berjalan efektif di sekolah.

\section{Pembahasan}

Berdasarkan hasil pengolahan data yang telah dilakukan sebelumnya, berikut ini dikemukakan pembahasan sesuai dengan pertanyaan penelitian yang diajukan oleh peran guru BK dalam meningkatkan motivasi belajar siswa melalui layanan informasi pada pelaksanaan layanan informasi yang dilakukan guru untuk memotivasi siswa melalui pengerjaan tugas-tugas sekolah peran guru BK/konselor untuk meningkatkan motivasi belajar siswa yang memiliki hasil belajar rendah telah terlaksana dengan baik. Hal ini dapat dilihat dari rata-rata persentase jawaban guru BK sebanyak 45\% siswa aktif, 15\% siswa perlu di ingatkan, 5\% kerja sama terhadap orangtua. agar siswa berhasil dalam belajarnya, perlu mengerjakan tugas-tugas dengan sebaik-baiknya. Bagi mereka yang terbiasa menunda-nunda waktu mengerjakan tugas tidak akan bisa menyelesaikan tugas tepat waktu, karena dengan menyelesaikan tugas tepat waktu akan mengurangi kecemasan pada diri siswa karena mereka tidak takut lagi dimarahi oleh guru. Oleh karena itu diharapkan siswa mampu mengatur waktu belajarnya sehingga dapat menumbuhkan kepercayaan diri dalam menyelesaikan tugas. Peran guru BK dalam pemberian informasi mengenai pelaksanaan proses pembelajaran di sekolah sudah terlaksana dengan baik. Hal ini dapat dilihat dari rata-rata persentase jawaban guru BK sebanyak $45 \%$. Untuk dapat mengikuti proses belajar yang baik diperlukan proses dan motivasi yang baik pula. Hal ini berarti melalui layanan informasi yang diberikan guru BK/konselor membuat siswa memperoleh pemahaman yang baik tentang bagaimana meningkatkan motivasi untuk mengikuti proses pembelajaran di sekolah karena akan berpengaruh terhadap hasil belajar yang 
mereka peroleh. Untuk itu jelas bahwa dalam proses pembelajaran, siswa harus aktif berbuat. Sehingga diperlukan peran dari guru BK untuk memberikan informasi serta membimbing siswa dalam mengembangkan motivasinya dalam proses pembelajaran, sehingga mampu membangkitkan dan mengembangkan keaktifan siswa dalam belajar. Peran guru BK dalam memotivasi siswa yang memiliki hasil belajar rendah dengan memberikan wawasan dan pemahaman untuk menghadapi ujian sudah terlaksana dengan baik. Hal ini dapat dilihat dari rata-rata persentase jawaban guru BK sebanyak 45\%. yang mengemukakan macam-macam keterampilan yang harus dimiliki siswa dalam belajar dan salah satunya keterampilan dalam menghadapi ujian,

Peran guru BK dalam meningkatkan motivasi belajar siswa melalui layanan konseling perorangan ialah siswa yang memiliki hasil belajar rendah melalui layanan konseling perorangan untuk motivasi intrinsik sudah terlaksana dengan cukup baik. Hal ini dapat dilihat dari ratarata persentase jawaban guru BK sebanyak 77,4\%. indikator-indikator yang termasuk motivasi belajar yang berasal dari dalam diri adalah minat, ketajaman perhatian, konsentrasi, dan ketekunan. Hal ini berarti layanan konseling perorangan yang dilakukan guru BK/konselor membuat siswa mampu meningkatkan motivasi belajar mereka secara intrinsik untuk meningkatkan hasil belajarnya. Peran guru BK dalam memotivasi siswa yang memiliki hasil belajar rendah melalui layanan konseling perorangan untuk motivasi ekstrinsik sudah terlaksana dengan baik. Hal ini dapat dilihat dari rata-rata persentase jawaban guru BK sebanyak $81,2 \%$. guru dapat memberikan motivasi ekstrinsik yaitu motivasi yang tujuannya (siswa) terletak di luar perbuatannya (siswa) agar siswa giat dalam belajarnya. Banyak siswa yang bergairah dan menampakkan aktivitas yang tinggi dalam belajar bukan karena memiliki motivasi berprestasi, tetapi karena dukungan sosial. Siswa-siswa seperti ini sangat membutuhkan dukungan sosial dalam belajar. Mereka menampakkan kegairahan dalam belajar, jika mereka mempunyai hubungan sosial yang akrab dengan guru dan teman sekelasnya.

\section{KESIMPULAN}

Berdasarkan hasil analisis data yang telah dibahas pada bab terdahulu tentang peran guru BK dan guru mata pelajaran dalam meningkatkan motivasi belajar siswa yang memiliki hasil belajar rendah, dapat disimpulkan bahwa pelaksanaan peran guru BK dan guru mata pelajaran, Dari hasil penelitian dan analisis data diatas, peran guru BK/Konselor dalam meningkatkan motivasi belajar siswa yang memperoleh hasil belajar rendah melalui layanan 
informasi dalam kategori baik. peran guru BK/Konselor dalam meningkatkan motivasi belajar siswa yang memperoleh hasil belajar rendah melalui layanan konseling perorangan dalam kategori cukup baik. Dari hasil penelitian dan analisis data diatas, peran guru mata pelajaran dalam meningkatkan motivasi belajar siswa yang memperolah hasil belajar rendah melalui kegiatan bimbingan di dalam kelas dalam kategori baik. peran guru mata pelajaran dalam meningkatkan motivasi belajar siswa yang memperoleh hasil belajar rendah melalui kegiatan bimbingan di luar kelas dalam kategori cukup baik.

\section{DAFTAR PUSTAKA}

Amani. 2018. Peran Guru Bimbingan Dan Konseling Dalam Memotivasi Belajar Siswa SMP Negeri 14 Yogyakarta. Jurnal Bimbingan Konseling dan Dakwah Islam. Vol. 15, No. 1. Universitas Islam Sunan Kalijaga Yogjakarta.

Ghoffar, Helmi. 2017. Upaya Guru Mata Pelajaran Dan Guru BK Dalam Mencegah Perilaku Menyontek (Studi Pada SMA Negeri Se-Kota Padangsidimpuan). Jurnal Wahana Didaktika Vol. 15 No. 3. Universitas Muhammadiyah Sumatera Utara.

Helma S. H. 2017. Peran Guru Bimbingan Dan Konseling Dalam Mengidentifikasi Permasalahan Belajar Peserta Didik Di Sma Negeri 1 Kandangan. Jurnal Mahasiswa BK An-Nur : Berbeda, Bermakna, Mulia. Vol. 3 No. 2. Universitas Islam Kalimantan MAB Banjarmasin.

Kusbandiami, dkk. 2017. Bimbingan dan Konseling Pribadi Sosial. Surabaya: Adi Buana University Press.

Marzuki, Aulia. 2017. Hubungan Motivasi Belajar Siswa. Medan: Uma.

Sugiyono. 2013. Metode Penelitian Pendidikan Pendekatan Kuantitatif Dan Kualitatif Dan $R \& D$. Bandung: Alfabeta. 